\title{
Factors Controlling the Gallium Preference in High-Al Chromitites
}

\author{
Ioannis-Porfyrios D. Eliopoulos * and George D. Eliopoulos
}

Department of Chemistry, University of Crete, Heraklion GR-70013, Crete, Greece; giorgoshliop@yahoo.gr

* Correspondence: disaca007@hotmail.com; Tel.: +30-281-054-5136

Received: 6 August 2019; Accepted: 7 October 2019; Published: 10 October 2019

Abstract: Gallium (Ga) belongs to the group of critical metals and is of noticeable research interest. Although $\mathrm{Ga}^{3+}$ is highly compatible in high-Al spinels a convincing explanation of the positive $\mathrm{Ga}^{3+}-\mathrm{Al}^{3+}$ correlation has not yet been proposed. In the present study, spinel-chemistry and geochemical data of high-Al and high-Cr chromitites from Greece, Bulgaria and the Kempirsai Massif (Urals) reveals a strong negative correlation ( $\mathrm{R}$ ranges from -0.95 to -0.98$)$ between $\mathrm{Cr} /(\mathrm{Cr}+\mathrm{Al}$ ) ratio and $\mathrm{Ga}$ in large chromite deposits, suggesting that Ga hasn't been affected by re-equilibration processes. In contrast, chromite occurrences of Pindos and Rhodope massifs show depletion in $\mathrm{Ga}$ and $\mathrm{Al}$ and elevated $\mathrm{Mn}, \mathrm{Co}, \mathrm{Zn}$ and Fe contents, resulting in changes (sub-solidus reactions), during the evolution of ophiolites. Application of literature experimental data shows an abrupt increase of the inversion parameter $(x)$ of spinels at high temperature, in which the highest values correspond to low- $\mathrm{Cr}^{3+}$ samples. Therefore, key factors controlling the preference of $\mathrm{Ga}^{3+}$ in high- $\mathrm{Al}$ chromitites may be the composition of the parent magma, temperature, redox conditions, the disorder degree of spinels and the ability of $\mathrm{Al}^{3+}$ to occupy both octahedral and tetrahedral sites. In contrast, the competing $\mathrm{Cr}^{3+}$ can occupy only octahedral sites (due to its electronic configuration) and the $\mathrm{Ga}^{3+}$ shows a strong preference on tetrahedral sites.

Keywords: chromite; gallium; spinel; structure; composition; correlation; ophiolites; disorder

\section{Introduction}

Gallium (Ga) is a vital metal for the economy, due to its use in high-technology applications, such as electronics industry, electric cars, solar panels. Although bauxite deposits are traditionally mined for their $\mathrm{Al}$ content and are important sources of $\mathrm{Ga}$ as a byproduct commodity [1], the distribution of $\mathrm{Ga}$ in chromite ores may be of particular research interest, due to its relationship with the major element composition of chromite.

Chromite belongs to the subgroup of spinels, which accommodate a wide variety of cations in their structure with the general formula $\mathrm{AB}_{2} \mathrm{O}_{4}$. Many authors emphasized that despite their simple structure, many spinels exhibit complex disordering phenomena involving the two cation sites, which play an important role both in their thermochemical and their physical properties [2-6]. The movements of cations between tetrahedral and octahedral sites, as a result of cation substitution, have been discussed under the aspect of structural parameters, such as tetrahedral and octahedral bond lengths, cation-cation and cation-anion distances, bond angles and hopping lengths, which were calculated by experimental lattice constants and oxygen parameters [2-4,7-12]. The ability of $\mathrm{Ga}^{3+}(\mathrm{r}=0.62 \AA)$ to replace $\mathrm{Al}^{3+}(\mathrm{r}=0.54 \AA)$ in aluminum minerals is related to their geochemistry (Group III of the periodic table), while Ga might be expected to behave in a similar way in chromite and magnetite as they share similar ionic radii $\left(\mathrm{Cr}^{3+}, \mathrm{r}=0.62 \AA ; \mathrm{Fe}^{3+}=0.64 \AA\right.$ ) for octahedral and tetrahedral coordination $\left(\mathrm{Al}^{3+}, \mathrm{r}=0.39 ; \mathrm{Ga}^{3+}=0.47 ; \mathrm{Fe}^{3+}=0.49\right)$ [3]. Gallium levels reported in Cr-spinel grains from ophiolites, varying from 10 to $50 \mathrm{ppm}[13,14]$ are consistent with experimental 
mineral-melt data on the partition coefficient $\left(\mathrm{D}_{\mathrm{Ga}}=0.9-11.2\right)$ [15]. Although mineral-melt partition coefficients are not constants, depending on a number of factors (pressure, temperature, oxygen fugacity or mineral and melt composition) on the basis of experimental data it has been suggested that $\mathrm{Ga}$ is volatile and there is no significant effect of temperature, magma composition and at very low oxygen fugacity conditions [15].

A tectonic discrimination of peridotites, using the oxygen fugacity $\left(\mathrm{fO}_{2}\right)-\mathrm{Cr} \#[\mathrm{Cr} /(\mathrm{Cr}+\mathrm{Al})]$ diagram, and the $\mathrm{Ga}-\mathrm{Ti}-\mathrm{Fe}^{3+} \#\left[\mathrm{Fe}^{3+} /\left(\mathrm{Fe}^{3+}+\mathrm{Cr}+\mathrm{Al}\right)\right]$ systematics in chrome-spinels, has been proposed [16]. A negative correlation between $\mathrm{Ga}$ and $\mathrm{Cr}$ in chromitites has been established, that may be related to the composition of parental magmas [17-24] or to the outer electronic structure of Ga that is similar to that of $\mathrm{Al}$ [25]. Also, the investigation of spinels in lithospheric mantle xenoliths from distinct tectonic settings has demonstrated that trace elements contribute in discriminating between spinels hosted in peridotites and those crystallized from magmas [11]. However, a convincing explanation of the positive correlation between $\mathrm{Ga}^{3+}$ and $\mathrm{Al}^{3+}$ has not yet been offered.

In the present study we characterize the spinel chemistry, bulk ore composition, including Ga, from chromitite samples of selected ophiolite complexes in Greece (Pindos, Central Vourinos and Skyros), the Rhodope-Serbo-Macedonian zone (SMZ) massifs (all of Mesozoic age) and the Kempirsai Massif (Kazakhstan) in the Urals (Palaeozoic age), all hosting both high-Cr and high-Al chromitites. The investigated samples are representative of large chromite deposits and small occurrences, in order to define potential relationships between major, minor or trace elements and Ga and the effect of re-equilibration processes, during a long evolutionary time of the ophiolites. We apply available platinum-group element (PGE) data to define potential correlations between the Ga content and fractional crystallization, and experimental literature data for the structure of spinels, aiming to investigate the role of intra-crystalline cation exchange, and contribute to still uncertain factors controlling the positive Al-Ga correlation of chromitites.

\section{Materials and Methods}

\subsection{Mineral Analysis}

Polished sections of all chromitite samples were examined using a reflected light microscope and a scanning electron microscope (SEM), equipped with energy-dispersive spectroscopy (EDS). The SEM-EDS back-scattered electron images (Figure 1) and analyses of chromite ores (Table 1) were carried out at the Faculty of Geology and Geoenvironment, National and Kapodistrian University of Athens (NKUA), using a JEOL JSM 5600 (Tokyo, Japan), scanning electron microscope, equipped with ISIS 300 OXFORD (Oxford shire, UK), automated energy dispersive analysis system. Analytical conditions were $20 \mathrm{kV}$ accelerating voltage, $0.5 \mathrm{nA}$ beam current, $<2 \mu \mathrm{m}$ beam diameter and $50 \mathrm{~s}$ count times. The following X-ray lines were used: $\mathrm{FeK} \alpha, \mathrm{NiK} \alpha, \operatorname{CoK} \alpha, \mathrm{CuK} \alpha, \operatorname{CrK} \alpha, \mathrm{AlK} \alpha, \operatorname{TiK} \alpha, \mathrm{CaK} \alpha$, $\mathrm{SiK} \alpha, \mathrm{MnK} \alpha$ and $\mathrm{MgK} \alpha$. Cr, $\mathrm{Fe}, \mathrm{Mn}, \mathrm{Ni}, \mathrm{Co}$, Ti and $\mathrm{Si}, \mathrm{MgO}$ for $\mathrm{Mg}$ and $\mathrm{Al}_{2} \mathrm{O}_{3}$ for Al. Contents of $\mathrm{Fe}_{2} \mathrm{O}_{3}$ and $\mathrm{FeO}$ were calculated on the basis of the spinel stoichiometry. 
Table 1. Electron scanning electron microscope (SEM)/energy-dispersive spectroscopy (EDS) analyses of chromite from chromitites of Greece, Bulgaria and Kempirsai (Urals).

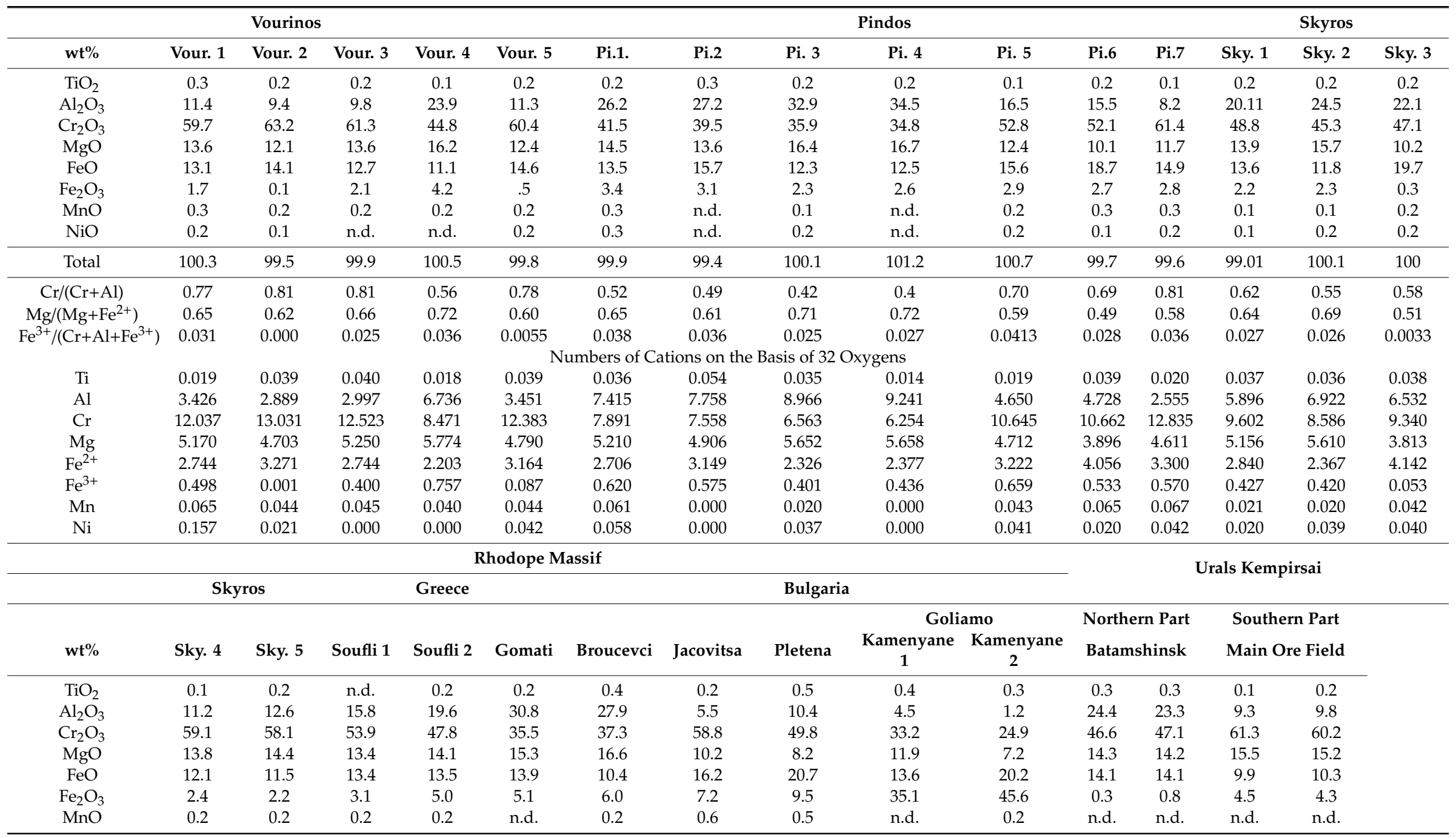


Table 1. Cont

\begin{tabular}{|c|c|c|c|c|c|c|c|c|c|c|c|c|c|c|}
\hline \multicolumn{11}{|c|}{ Rhodope Massif } & \multirow{2}{*}{\multicolumn{4}{|c|}{ Urals Kempirsai }} \\
\hline \multirow[b]{3}{*}{$\mathbf{w t} \%$} & \multicolumn{2}{|c|}{ Skyros } & \multicolumn{3}{|c|}{ Greece } & \multicolumn{5}{|c|}{ Bulgaria } & & & & \\
\hline & \multirow[b]{2}{*}{ Sky. 4} & \multirow[b]{2}{*}{ Sky. 5} & \multirow[b]{2}{*}{ Soufli 1} & \multirow[b]{2}{*}{ Soufli 2} & \multirow[b]{2}{*}{ Gomati } & \multirow[b]{2}{*}{ Broucevci } & \multirow[b]{2}{*}{ Jacovitsa } & \multirow[b]{2}{*}{ Pletena } & \multicolumn{2}{|c|}{ Goliamo } & \multirow{2}{*}{\multicolumn{2}{|c|}{$\begin{array}{l}\text { Northern Part } \\
\text { Batamshinsk }\end{array}$}} & \multirow{2}{*}{\multicolumn{2}{|c|}{$\begin{array}{l}\text { Southern Part } \\
\text { Main Ore Field }\end{array}$}} \\
\hline & & & & & & & & & $\begin{array}{c}\text { Kamenyane } \\
1\end{array}$ & $\begin{array}{c}\text { Kamenyane } \\
2\end{array}$ & & & & \\
\hline $\mathrm{NiO}$ & 0.2 & 0.2 & n.d. & 0.2 & n.d. & 0.2 & 0.2 & 0.2 & 0.3 & 0.4 & 0.2 & 0.2 & 0.1 & 0.3 \\
\hline Total & 99.1 & 99.7 & 100.2 & 99.8 & 100.3 & 99.1 & 99.1 & 100 & 99.2 & 99.9 & 100.4 & 99.9 & 100.8 & 100.3 \\
\hline $\mathrm{Cr} /(\mathrm{Cr}+\mathrm{Al})$ & 0.75 & 0.79 & 0.70 & 0.63 & 0.44 & 0.47 & 0.88 & 0.74 & 0.83 & 0.94 & 0.56 & 0.58 & 0.82 & 0.80 \\
\hline $\mathrm{Mg} /\left(\mathrm{Mg}+\mathrm{Fe}^{2+}\right)$ & 0.68 & 0.69 & 0.62 & 0.65 & 0.66 & 0.72 & 0.52 & 0.37 & 0.52 & 0.38 & 0.64 & 0.65 & 0.74 & 0.73 \\
\hline $\mathrm{Fe}^{3+} /\left(\mathrm{Cr}+\mathrm{Al}+\mathrm{Fe}^{3+}\right)$ & 0.03 & 0.026 & 0.036 & 0.059 & 0.057 & 0.068 & 0.093 & 0.123 & 0.455 & 0.62 & 0.0015 & 0.009 & 0.053 & 0.052 \\
\hline \multicolumn{15}{|c|}{ Numbers of cations on the basis of 32 oxygens } \\
\hline $\mathrm{Ti}$ & 0.019 & 0.038 & 0.019 & 0.036 & 0.035 & 0.035 & 0.041 & 0.102 & 0.082 & 0.062 & 0.054 & 0.054 & 0.019 & 0.038 \\
\hline $\mathrm{Al}$ & 3.414 & 3.813 & 4.636 & 5.591 & 8.475 & 7.828 & 1.767 & 3.277 & 1.452 & 0.386 & 6.987 & $6 ., 675$ & 2.787 & 2.947 \\
\hline $\mathrm{Cr}$ & 12.066 & 11.695 & 10.745 & 9.396 & 6.553 & 7.021 & 12.670 & 10.582 & 7.168 & 5.648 & 8.880 & 9.070 & 12.323 & 12.143 \\
\hline $\mathrm{Mg}$ & 5.321 & 5.512 & 5.036 & 5.231 & 5.324 & 5.890 & 4.143 & 3.291 & 4.858 & 3.088 & 5.137 & 5.151 & 5.874 & 5.780 \\
\hline $\mathrm{Fe}^{2+}$ & 2.613 & 2.442 & 2.940 & 2.805 & 2.711 & 2.067 & 3.715 & 4.653 & 3.114 & 4.839 & 2.879 & 2.864 & 2.125 & 2.197 \\
\hline $\mathrm{Fe}^{3+}$ & 0.480 & 0.414 & 0.580 & 0.940 & 0.901 & 1.079 & 1.481 & 1.936 & 7.215 & 9,844 & 0.024 & 0.146 & 0.852 & 0.833 \\
\hline $\mathrm{Mn}$ & 0.044 & 0.044 & 0.043 & 0.000 & 0.000 & 0.040 & 0.138 & 0.115 & 0.000 & 0.046 & 0.000 & 0.000 & 0.000 & 0.000 \\
\hline $\mathrm{Ni}$ & 0.041 & 0.041 & 0.000 & 0.000 & 0.000 & 0.038 & 0.044 & 0.044 & 0.114 & 0.088 & 0.039 & 0.038 & 0.020 & 0.062 \\
\hline
\end{tabular}




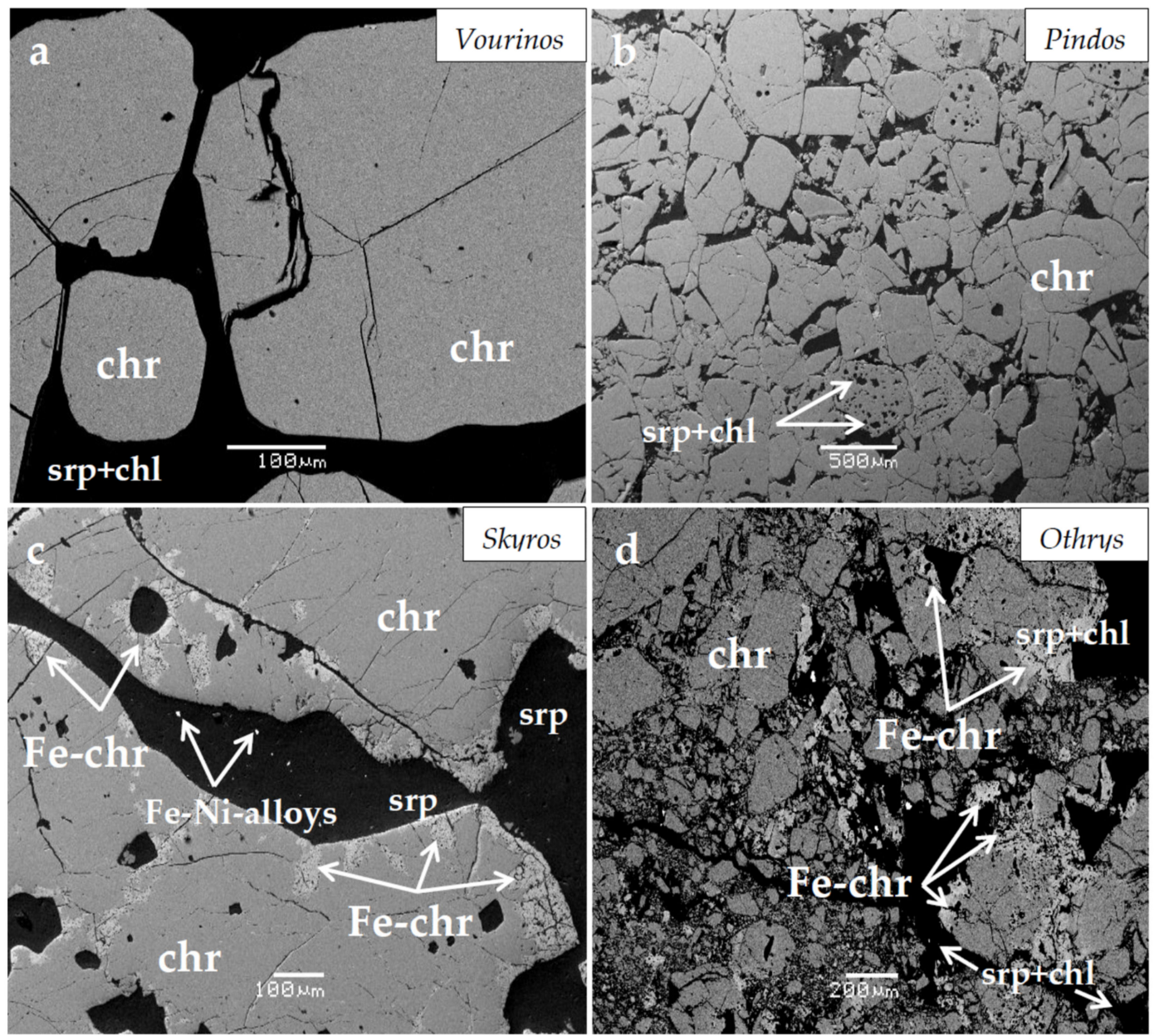

Figure 1. Representative back-scattered electron images of chromite ores from Greece, showing texture relationships between chromite and silicates, the presence of homogeneous chromite (a) and also abundant silicate inclusions (chlorite and serpentine) in the host chromite (b), porous texture and alteration to Fe-chromite $(\mathbf{c}, \mathbf{d})$. Abbreviations: $\mathrm{chr}=$ chromite; Fe-chr = iron-chromite; srp = serpentine; chl $=$ chlorite .

\subsection{Whole Rock Analysis}

Major and trace elements in massive chromitite samples (more than $95 \mathrm{vol} \%$ ) were determined by ICP-MS analysis, at the ACME Analytical Laboratories Ltd., Vancouver, BC, Canada (currently Bureau Veritas Commodities Canada Ltd.). The samples were dissolved using an acid mix $\left(\mathrm{HNO}_{3}-\mathrm{HClO}_{4}-\mathrm{HF}\right)$ digestion and then the residues were dissolved in concentrated $\mathrm{HCl}$. The rare earth elements $\mathrm{La}, \mathrm{Ce}$, $\mathrm{Pr}, \mathrm{Nd}, \mathrm{Sm}, \mathrm{Eu}, \mathrm{Gd}, \mathrm{Tb}$, Dy, Ho, Er, Tm, Yb and $\mathrm{Lu}$ as well as Li, K, Ge, Sr, Y, Zr, Mo, Sb, Cs, W, Pb, $\mathrm{Th}$, and $\mathrm{U}$ were lower than the detection limits of the analytical methods. The detection limits of the method for the presented elements are $1 \mathrm{ppm}$ for Ga and V, $0.2 \mathrm{ppm}$ for $\mathrm{Co}$ and $\mathrm{Zn}, 0.1$ for $\mathrm{Ni}$ and $0.01 \mathrm{wt} \%$ for Fe. On the basis of the quality control report provided by the Analytical Labs, the results of analyses of the reference material in comparison to expected values, and the results from multistage analysis of certain samples, showed accuracy and precision in good agreement with accepted values for international standards. The analytical error, for $\mathrm{Ga}$, for example, was $<5 \%$. Although the PGE data reported in Table 2 have been published previously (Table 2) a portion from the same samples was used for the presented trace element analyses. 
Table 2. Trace element contents of high- $\mathrm{Cr}$ and high-Al chromitites.

\begin{tabular}{|c|c|c|c|c|c|c|c|c|c|c|}
\hline \multirow{2}{*}{ Location } & \multicolumn{2}{|c|}{ SEM/EDS } & \multicolumn{5}{|c|}{ Trace Element (ppm) } & \multirow{2}{*}{$\begin{array}{c}\mathrm{wt} \% \\
\mathrm{Fe}\end{array}$} & \multicolumn{2}{|l|}{$\mathrm{ppb}$} \\
\hline & $\mathrm{Cr} /(\mathrm{Cr}+\mathrm{Al})$ & $\mathrm{Mg} /\left(\mathrm{Mg}+\mathrm{Fe}^{2+}\right)$ & $\mathbf{N i}$ & Co & $\mathbf{V}$ & $\mathrm{Zn}$ & Ga & & $\Sigma \mathrm{PGE}^{*}$ & $\mathbf{P d} / \mathbf{I r}$ * \\
\hline Vourinos 1 & 0.77 & 0.65 & 2000 & 240 & 500 & 260 & 14 & 8.1 & 140 & 0.06 \\
\hline Vourinos 2 & 0.81 & 0.62 & 1580 & 210 & 560 & 550 & 15 & 7.9 & 135 & 0.35 \\
\hline Vourinos 3 & 0.81 & 0.66 & 1900 & 200 & 400 & 300 & 13 & 8.72 & 92 & 0.55 \\
\hline Vourinos 4 & 0.56 & 0.72 & 1800 & 170 & 780 & 360 & 27 & 9.2 & 30 & 0.54 \\
\hline Vourinos 5 & 0.78 & 0.61 & 1800 & 180 & 620 & 280 & 14 & 7.76 & 109 & 0.63 \\
\hline Pindos 1 & 0.52 & 0.63 & 1300 & 140 & 600 & 400 & 23 & 7.84 & 51 & 1.0 \\
\hline Pindos 2 & 0.48 & 0.6 & 1500 & 260 & 710 & 410 & 32 & 9.77 & 143 & 1.0 \\
\hline Pindos 3 & 0.42 & 0.71 & 1500 & 260 & 710 & 520 & 34 & 7.8 & 117 & 6.33 \\
\hline Pindos 4 & 0.4 & 0.72 & 1630 & 240 & 580 & 460 & 32 & 7.3 & 6123 & 34.2 \\
\hline Pindos5 & 0.67 & 0.57 & 750 & 270 & 760 & 520 & 16 & 9.7 & 3875 & 12.2 \\
\hline Pindos 6 & 0.69 & 0.49 & 720 & 240 & 760 & 620 & 23 & 10.1 & 2098 & 7.2 \\
\hline Pindos 7 & 0.81 & 0.58 & 1450 & 290 & 560 & 490 & 17 & 10.2 & 181 & 0.22 \\
\hline Skyros 1 & 0.61 & 0.64 & 1300 & 250 & 1200 & 540 & 34 & 10.9 & 2300 & 0.08 \\
\hline Skyros 2 & 0.55 & 0.69 & 1600 & 200 & 1000 & 400 & 36 & 9.45 & 464 & 0.7 \\
\hline Skyros 3 & 0.58 & 0.51 & 1500 & 240 & 870 & 450 & 40 & 9.6 & 251 & 0.67 \\
\hline Skyros 4 & 0.75 & 0.69 & 1250 & 220 & 640 & 420 & 14 & 10.7 & 145 & 0.33 \\
\hline Skyros 5 & 0.79 & 0.69 & 1200 & 200 & 620 & 400 & 11 & 10.1 & 145 & 0.1 \\
\hline Othrys $(n=4)$ & 0.54 & 0.69 & 1400 & 210 & 960 & 370 & 33 & 9.8 & 91 & 0.36 \\
\hline \multicolumn{11}{|l|}{ Rhodope Massif } \\
\hline Soufli1 & 0.70 & 0.62 & 1700 & 230 & 380 & 580 & 16 & 13.2 & 150 & 0.2 \\
\hline Soufli2 & 0.63 & 0.65 & 1150 & 220 & 460 & 280 & 12 & 10.6 & 82 & 1.0 \\
\hline Gomati & 0.49 & 0.67 & 1030 & 130 & 730 & 280 & 24 & 9.6 & 104 & 0.25 \\
\hline \multicolumn{11}{|l|}{ Bulgaria } \\
\hline Broucevci & 0.47 & 0.72 & 1300 & 230 & 790 & 420 & 45 & 11 & 60 & 0.92 \\
\hline Jacovitsa & 0.88 & 0.52 & 2250 & 310 & 240 & 760 & 9 & 13.9 & 197 & 0.46 \\
\hline Pletena & 0.74 & 0.37 & 890 & 290 & 330 & 1030 & 13 & 17.9 & 563 & 0.07 \\
\hline Goliamo Kamenyane 1 & 0.83 & 0.52 & 1550 & 80 & 1000 & 450 & 12 & 11.6 & 87 & 0.14 \\
\hline Goliamo Kamenyane 2 & 0.94 & 0.38 & 2260 & 970 & 370 & 4030 & 6 & 64.3 & 40 & 1.93 \\
\hline \multicolumn{11}{|l|}{ Kemprsai (Urals) } \\
\hline Northern & 0.80 & 0.73 & 1600 & 210 & 160 & 160 & 14 & 9.1 & & \\
\hline Batamshinsk & 0.82 & 0.74 & 1600 & 230 & 200 & 190 & 16 & 9.5 & & \\
\hline Southern & 0.56 & 0.58 & 1500 & 240 & 680 & 480 & 48 & 12.6 & & \\
\hline XL Let Kazakhstan & 0.64 & 0.65 & 1700 & 230 & 730 & 340 & 49 & 10.1 & & \\
\hline
\end{tabular}

Symbol $^{*}=$ Data on PGE from literature [26-32]. 


\section{A Brief Outline of Characteristics for the Studied Chromitites}

All chromitite samples selected for the present study come from deposits and occurrences, which have been the subject of detailed geological, mineralogical and geochemical investigation [26-36] and references therein. The main ophiolite complexes of Greece (Vourinos, Othrys and Pindos) belong to the Upper Jurassic to Lower Cretaceous Tethyan ophiolite belt, and are characterized by heterogeneous deformation and rotation, during their original displacement and subsequent tectonic incorporation into continental margins [33]. The studied samples of chromitites are massive (Figure 1) and exhibit variations in the chromitite tonnage, the composition of chromite (Tables 1 and 2), the degree of transformation of ores and the associated ophiolites [27-37].

Chromite ores in the Vourinos complex occur in the mantle and cumulate sequences, with a tonnage estimated to approximately $10 \mathrm{Mt}$ of high-Cr type, but at the central part of the complex there are high-Cr and high-Al ores in a spatial association, with low PGE contents [26]. The Othrys complex has a relatively high tonnage (approximately $3 \mathrm{Mt}$ ) of high-Al massive chromite ores and low PGE content [27].

The chromitite occurrences in the Pindos ophiolite complex are small (a few tens of $m(x)$ a few tens of $\mathrm{cm}$ ) and are hosted within completely serpentinized and weathered, intensively deformed dunite-harzburgite blocks, due to a strong plastic and brittle deformation that was superimposed on primary magmatic textures $[17,18,34]$. Chromitites throughout the Pindos complex are high-Cr and high-Al, often in a spatial association. The most salient feature of the Pindos chromitites is the enrichment in $\mathrm{Pt}$ and Pd at the area of Korydallos, at a level of 7 ppm PGE total $[28,29]$ and up to $29 \mathrm{ppm}$ [35]. In the Achladones area on the Skyros island small massive chromitite bodies are of high-Al type and have elevated PGE contents, up to 3 ppm $\Sigma$ PGE, although both high-Cr and high-Al types having low PGE content are found on the entire island [30].

Ophiolites associated with the Serbomacedonian massif (Gomati) and Rhodope massif including the ophiolites of Soufli (Greece), Dobromirci, Jacovitsa, Broucevci and Goliamo-Kamenjane (Bulgaria) host small (a few thousand tons) high- $\mathrm{Cr}$ and high-Al ores in a spatial are association, which occasionally contain elevated PGE concentrations. They are completely serpentinized, locally sheared and metamorphosed to antigorite-tremolite and/or talc schists. Detailed description of the characteristic mineralogy and texture of those chromitites have been published in previous studies $[17,18,31,32,36]$.

The Kempirsai massif, covering an area of $2000 \mathrm{~km}^{2}$, is divided by a shear zone into two parts: the southeastern part that is called Main Ore Field (MOF), hosting large high-Cr chromite deposits, and the northwestern area, the so-called Batamshinsk Ore Field (BOF), hosting much smaller high-Al chromite deposits [37]. An excellent description of the petrography and mineral chemistry, including mineral inclusions in the chromite of the giant chromite deposit of Kempirsai has been provided and discussed by Melcher et al [37]. These authors have interpreted their formation by a multistage process: High-Al chromitites may be derived from MORB-type tholeiitic melts, and high-Cr ones from boninitic magmas, during a second stage by interaction of hydrous high-Mg melts and fluids with depleted mantle in a supra-subduction zone setting.

\section{Results}

\subsection{Compositional Variations in Chromite}

The chromite samples from the central part of the Vourinos complex, the Pindos, Skyros island, Serbomacedonian, Rhodope and Kempirsai massifs show a wide variation in major elements from high-Cr, with the $\mathrm{Cr} /(\mathrm{Cr}+\mathrm{Al})$ atomic ratio ranging from 0.81 to 0.69 , to high- $\mathrm{Al}$ with the $\mathrm{Cr} / \mathrm{Cr}+$ $\mathrm{Al}$ ) ratio ranging from 0.63 to 0.4 (Table 1), falling in the range of metallurgical and refractorytype, respectively [21]. In addition, in the Bulgarian Rhodope massif (Jacovitsa, Pletena and Goliamo Kamenyane areas) altered chromite grains are dominant, having relatively high $\mathrm{FeO}$ and low $\mathrm{Al}_{2} \mathrm{O}_{3}$ and $\mathrm{MgO}$ contents (Table 1$)$. As a consequence, the $\mathrm{Cr} /(\mathrm{Cr}+\mathrm{Al})$ atomic ratios of those chromitites are significantly higher than those of high-Cr chromitites from the Vourinos complex (Table 1). 


\subsection{Distribution of Trace Elements in Chromitites}

The geochemical data from whole rock analyses show a wide variation in major and trace element contents (Table 2). Gallium contents are lower in high-Cr chromitites (11 to $23 \mathrm{ppm}$ ) compared to high-Al ones (27-49 ppm), that seems to be independent on the degree of fractionation of parent magma, as exemplified by the Pd/Ir ratio [38]. The highest Co, Mn, Zn, Fe and lowest Ga were mainly recorded in strongly altered small chromite occurrences from the Rhodope massif in Bulgaria. They are in a good agreement with other chromitites [21-25] and are independent of the age of the associated ophiolites. Platinum-group elements (PGE) show total contents ranging from 30 to $6120 \mathrm{ppb}$ and Pd/Ir ratios from 0.06 to 34, which are independent of the major element composition of chromitites (Table 2).

The results show a strong negative correlation ( $R$ ranges from -0.98 to -0.95 ) between the $\mathrm{Cr} / \mathrm{Cr}$ $+\mathrm{Al}$ ) atomic ratio and Ga for the relatively large chromite deposits of Vourinos, Kempirsai massif (Urals) and the Skyros island. In addition, there is a less strong negative correlation for small chromite occurrences from the Pindos and Rhodope massifs ( $R \geq-0.76$ and $R \geq-0.83$, respectively). Apart from $\mathrm{Ga}$, the best correlation is found between $\mathrm{Cr} /(\mathrm{Cr}+\mathrm{Al})$ and $\mathrm{V}$ for the Vourinos $(\mathrm{R}=-0.84)$, Skyros and Kempirsai ( $R \geq-0.93$ ), whereas no significant relationship for chromitites from the Pindos and Rhodope massifs (Figure $2 \mathrm{~b}$ ) or between $\mathrm{Cr} /(\mathrm{Cr}+\mathrm{Al})$ and other minor and trace elements is observed.
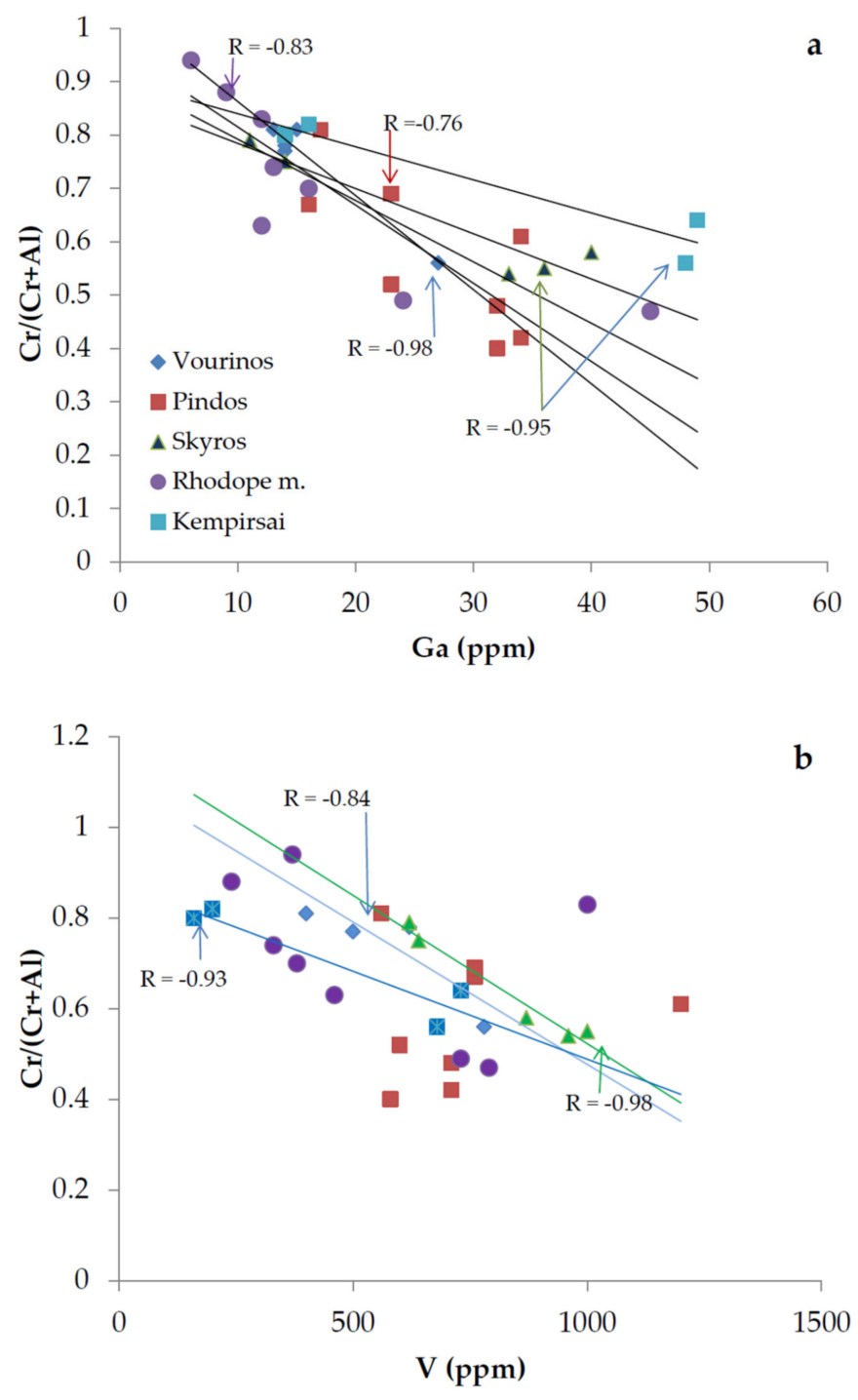

Figure 2. Cont. 


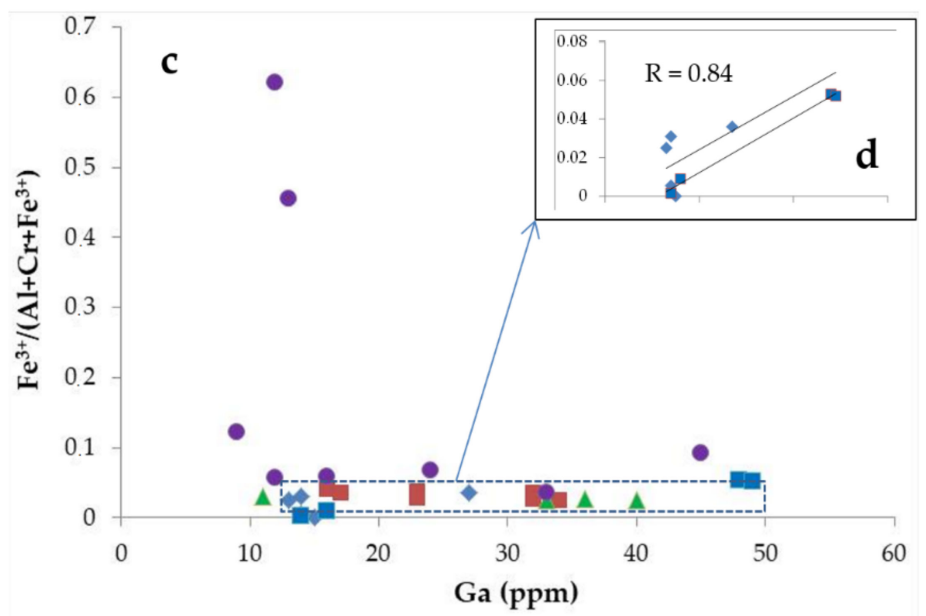

Figure 2. Plots of the $\mathrm{Cr} /(\mathrm{Cr}+\mathrm{AI})$ atomic ratio versus $\mathrm{Ga}$ content $(\mathbf{a})$; the $\mathrm{Cr} /(\mathrm{Cr}+\mathrm{AI})$ ratio versus $\mathrm{V}$ content (b) and the $\mathrm{Fe}^{3+} /\left(\mathrm{Al}+\mathrm{Cr}+\mathrm{Fe}^{3+}\right)$ ratio versus $\mathrm{Ga}$ content $(\mathbf{c})$, including a detailed plot for the Vourinos and Kempirsai samples (d). Data from the Table 2.

\section{Discussion}

\subsection{Factors Controlling the Spinel Chemistry}

\subsubsection{Magmatic Versus Post-Magmatic Processes}

The wide variation of the $\mathrm{Cr} /(\mathrm{Cr}+\mathrm{Al})$ atomic ratio for the chromitite samples from Greece, Bulgaria and Kempirsai massifs (Tables 1 and 2) fall in the range of metallurgical and refractory types. Differences in the trace element content (Table 2) may suggest trace element partitioning, depending on a number of factors, such as temperature, pressure, oxygen fugacity and the chemical composition of parent magmas [17-47].

As the partition coefficient of elements is defined as the ratio of the element content in a mineral and the melt [15], the Pd/Ir ratio can be used as an indicator of the degree of fractionation of parent magma for chromitites [38] and the presence of very low $\mathrm{Pd} / \mathrm{Ir}$ values (low degree of fractionation) for both high- $\mathrm{Cr}$ and high-Al chromitites, suggest their origin from different magma sources. It has been argued that high-Cr chromitites, which have higher Sc, Mn, Co and Ni, and lower Ti, V, Zn and Ga contents may be derived from boninitic magmas, while high-Al ores may be derived from MORB-type tholeiitic magmas [17-24]. Experimental data at high temperature have shown that Ga is compatible in spinel with $\mathrm{D}$ values ranging between 0.9 and 11.2, and slightly lower D values in the most reducing experiments, while experimental data at temperatures $>1300^{\circ} \mathrm{C}$ and low oxygen fugacity have shown that there is no significant effect of temperature, composition and redox conditions [15]. However, the negative correlation between the $\mathrm{Cr} /(\mathrm{Cr}+\mathrm{Al})$ atomic ratio and $\mathrm{Ga}$ content in natural chromitites points to the potential effect of the composition of the parent magma, while a positive trend between the $\mathrm{Fe}^{3+} /\left(\mathrm{Al}+\mathrm{Cr}+\mathrm{Fe}^{3+}\right)$ atomic ratio and Ga content for large chromite deposits (Figure 2c,d) may suggest the effect of the redox conditions on the Ga distribution in chromitites. Specifically, high-Cr chromitites formed earlier from a primary magma (under relatively reducing conditions), compared to high-Al ones formed later from an evolved magma (and more oxidized conditions) magma [47].

In addition, differences in the negative correlations between the $\mathrm{Cr} /(\mathrm{Cr}+\mathrm{Al})$ atomic ratio and $\mathrm{Ga}$ content and the slope of correlation lines for the different occurrences (Figure 2) may suggest that in addition to the composition of parent magmas, which is a major factor for large deposits (like Vourinos and Kempirsai massif, Urals) other factors such as temperature, pressure or redox conditions may be responsible for the observed deviation from linearity for small metamorphosed occurrences of chromitites, such as those from the Pindos and Rhodope massifs (Figure 2b). The lack of significant relationships between major and trace elements, in small chromitite occurrences from the Pindos 
and Rhodope massifs (Figure 2) may be related with post-magmatic processes. The elevated Mn, $\mathrm{Co}, \mathrm{Zn}$ and Fe contents and depletion in Ga (Table 2) is consistent with the spinel chemistry in the Rhodope massif of Bulgaria, showing a trend of depletion in $\mathrm{Ga}$, in the metamorphic Fe-chromite rims surrounding the cores of chromite grains, implying that most tetrahedral sites are still occupied by $\mathrm{Fe}^{2+}$ [17]. In addition, it has been suggested that the $\mathrm{Mg}$ cations can be replaced by $\mathrm{Mn}, \mathrm{Zn}$ or $\mathrm{Co}$, whereas $\mathrm{Al}$ and $\mathrm{Fe}^{3+}$ compete for the octahedral sites, hampering the entry of $\mathrm{Ga}[17,18,24]$.

Despite the recorded modification in trace elements by re-distribution during post-magmatic processes, as exemplified by bulk analysis (Tables 1 and 2) and spinel chemistry [17,18,24] limited only to relatively small chromitite occurrences, the well-established relationship $(\mathrm{R}=-0.95$ to -0.98$)$ between $\mathrm{Cr} /(\mathrm{Cr}+\mathrm{Al})$ ratio and $\mathrm{Ga}$ (Table 2; Figure 1a) that is comparable to literature data for chromitites hosted in other ophiolite complexes [21-24,40-47] seems to be a salient feature.

\subsubsection{Spinel Structure}

The structure of spinel is a cubic close-packed array of 32 oxygen ions, with 64 tetrahedral vacancies and 32 octahedral vacancies in one unit cell each, containing 8 formula units, with the general formula: $\mathrm{A}^{2+} \mathrm{B}^{3+}{ }_{2} \mathrm{O}_{4}$, where $\mathrm{A}=\mathrm{Fe}^{2+}, \mathrm{Mn}^{2+}, \mathrm{Mg}^{2+}, \mathrm{Co}^{2+}, \mathrm{Zn}^{2+}, \mathrm{Ni}^{2+}$ and $\mathrm{B}=\mathrm{Fe}^{3+}, \mathrm{Cr}^{3+}, \mathrm{Al}^{3+}, \mathrm{Ga}^{3+}$, $\mathrm{V}^{3+}$ [36]. Spinels are traditionally denoted as either "normal", where the A cation occupies $\mathrm{T}$ sites, the B cation occupies M sites, whereas in the "inverse" type cation B occupies the T site and the M site is occupied by both cations A and B [4,8-12]. The degree of inversion $\mathrm{x}$ characterizing the cation distribution can show values between $x=0$ (normal spinel) and $x=1$ (inverse spinel). The spinel structure is able to accommodate many cations (at least 36) by enlarging and decreasing its tetrahedral and octahedral bond distances, while the oxygen positional parameter $(u)$ should be regarded as a measure of distortion of the spinel structure from cubic close packing or as the angular distortion of the octahedron $[10,12]$. The movements of cations between tetrahedral $\mathrm{T}$ and octahedral $\mathrm{M}$ sites, as a result of $\mathrm{Mg}^{2+}$ substitution, can be discussed based on structural parameters, such as bond lengths, cation-cation and cation-anion distances, bond angles and hopping lengths, which were calculated using experimental lattice constants and oxygen parameters [4,8-12].

\subsubsection{Applications to Natural Spinels}

Despite post-magmatic compositional changes in Fe-chromite within the chromitite ores, resulting in the remobilization of cations during metamorphism $\left(700^{\circ} \mathrm{C}\right.$ to $\left.450{ }^{\circ} \mathrm{C}\right)$ of chromitites $[17,18,21,24,32]$, the structural incorporation of $\mathrm{Ga}$ into the chromite lattice is evidenced by the progressive and linear increase of $\mathrm{Al}$ or decreasing $\mathrm{Cr} /(\mathrm{Cr}+\mathrm{Al}$ ) atomic ratio (Figure 2a). Experimental data on cation distribution versus temperature may provide valuable information related to the preferences of cations in the spinel lattice. $\mathrm{MgAl}_{2} \mathrm{O}_{4}$ is the most prominent example of a normal spinel because $\mathrm{Mg}^{2+}$ is much larger than $\mathrm{Al}^{3+}[2,6,48]$. Gallium $\left(\mathrm{Ga}^{3+}\right)$ is smaller than $\mathrm{Mg}^{2+}$, but significantly larger compared to $\mathrm{Al}^{3+}$, leading to an ordering which is called mainly inverse, at least for the end-member composition $\mathrm{MgGa}_{2} \mathrm{O}_{4}[4]$.

The intra-crystalline exchange reaction in spinels has been modeled $[49,50]$ and the order-disorder process has been described by the following exchange reaction: ${ }^{\mathrm{T}} \mathrm{Al}+{ }^{\mathrm{M}} \mathrm{Mg}={ }^{\mathrm{T}} \mathrm{Mg}+{ }^{\mathrm{M}} \mathrm{Al}$ (where $\mathrm{T}=$ tetrahedral and $\mathrm{M}=$ octahedral site) in which the forward reaction implies an exchange of $\mathrm{Mg}$ with $\mathrm{Al}$ at the $\mathrm{M}$ site (ordering process), and backwards (disordering process). The cation distributions for both disordering and ordering experiments were obtained by measuring the oxygen positional parameter $(\mathrm{u})$, the inversion parameter $(\mathrm{x})(\mathrm{Al}$ in $\mathrm{T})$ site, using samples with varying composition. The Mueller kinetic model was satisfactory applied to the experimental data and allowed the calculation of the kinetic ordering constants $\mathrm{K}$, linearly related to temperature by means of Arrhenius equations [48-51].

Martignago et al. [52] performed crystal structure refinements on three natural spinels, on low-Cr spinel containing small $\mathrm{Fe}^{3+}$ quantities and two other samples with high $\mathrm{Cr}\left(8.4 \mathrm{wt} \% \mathrm{Cr}_{2} \mathrm{O}_{3}\right)$ and low $\mathrm{Cr}\left(3.3 \mathrm{wt} \% \mathrm{Cr}_{2} \mathrm{O}_{3}\right)$ contents [52]. These experiments have shown that both parameters $(\mathrm{u})$ and 
(x) remained constant for the three different samples up to $600{ }^{\circ} \mathrm{C}$, independently of $\mathrm{Cr}^{3+}$ contents. The distortion of spinels, started at higher temperature, near to $650{ }^{\circ} \mathrm{C}$ (Figure 3). The degree of distortion at the highest temperatures is inversely correlated with $\mathrm{Cr}^{3+}$ contents. Since $\mathrm{Cr}^{3+}$ has a tendency to be completely partitioned on the octahedral site, due to its electronic configuration and size $[2,52-54], \mathrm{Al}^{3+}$ cation is unable to substitute $\mathrm{Cr}^{3+}$. The most salient feature derived from the above experimental data [52] is the abrupt increase of the inversion parameter (x) having the highest values for the sample with the lowest $\mathrm{Cr}$ content (L-Cr sample), and the lowest values for the sample with the highest $\mathrm{Cr}$ content (H-Cr) [52].

Such structural changes should cause modifications of the structural, physical and thermal properties of the spinels. Although the spinel structure is complicated and determination of several parameters may be required, the above results [52], which show that the $\mathrm{Cr}$ content in spinels affects the occupancy of $\mathrm{Al}$ in the tetrahedral site, may suggest that the co-existence of $\mathrm{Ga}^{3+}$ in high-Al chromitites (Table 2) [2,4-12] is related to the degree of disorder that is inversely correlated with Cr contents.

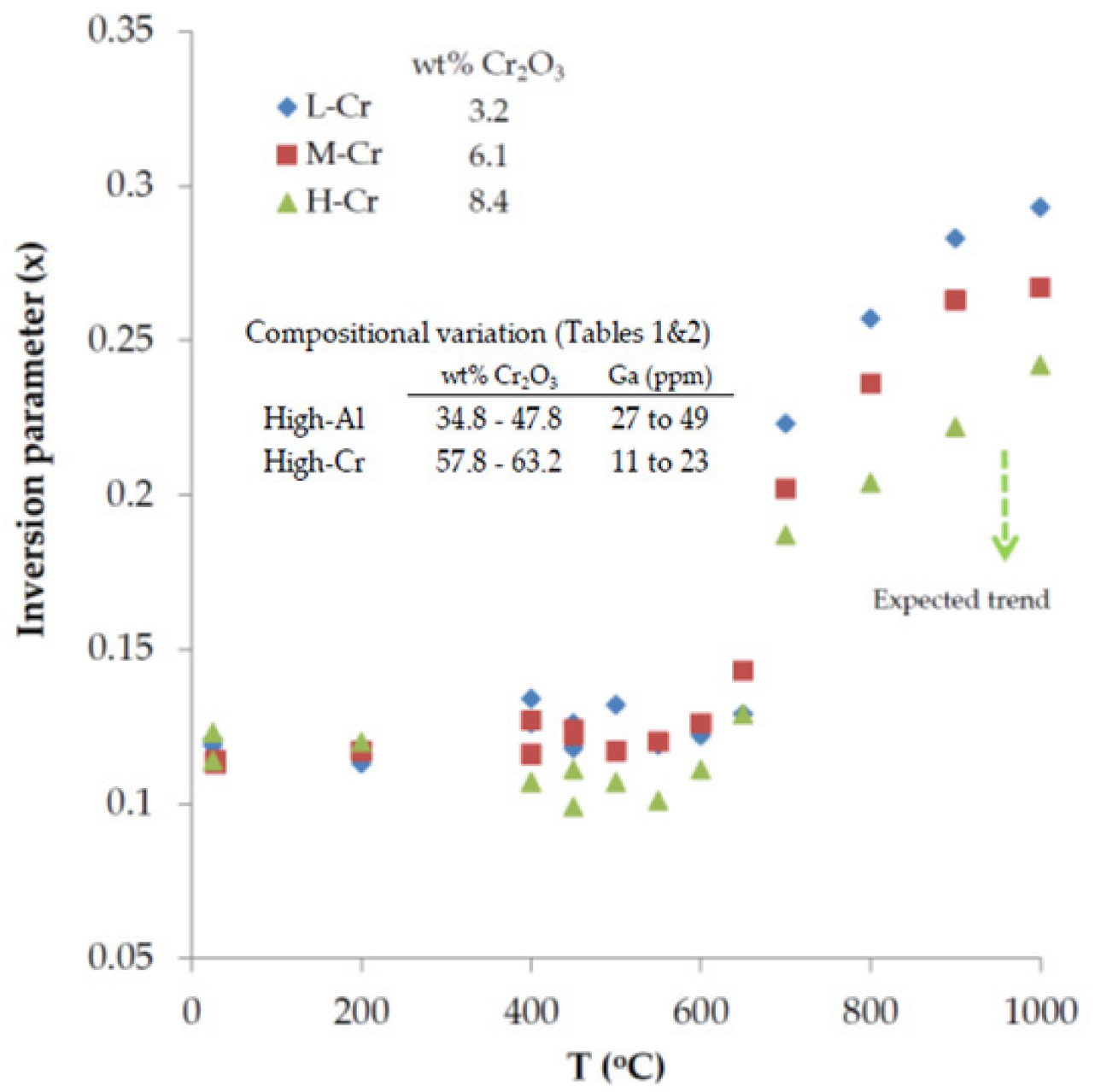

Figure 3. Plot of the Inversion parameter $(\mathrm{x})$ versus temperature for spinels after [52]. A potential trend for chromitites with much higher $\mathrm{Cr}$ content (Table 1) is presented by the green arrow.

Therefore, potential controlling factors on the Ga preference in high-Al chromitites are (a) the composition of the parent magma (geotectonic setting), temperature and redox conditions, (b) the electronic configuration of $\mathrm{Cr}^{3+}$ resulting in occupation of $\mathrm{M}$ sites only, the ability of $\mathrm{Al}^{3+}$ to occupy $\mathrm{T}$ and $\mathrm{M}$ sites and the strong preference of $\mathrm{Ga}^{3+}$ to $\mathrm{T}$ sites, and (c) elevated values of the inversion parameter $(x)$ that is inversely correlated with $\mathrm{Cr}^{3+}$ content and favors the co-existence of $\mathrm{Ga}^{3+}$ in high-Al chromitites. 


\section{Conclusions}

The presented geochemical and mineral chemistry data on chromitites associated with ophiolite complexes, in conjunction with experimental literature data allowed us to draw the following conclusions:

(1) The lower Ga contents in high-Cr chromitites (11 to $23 \mathrm{ppm}$ ) compared to high-Al ones (27-49 ppm) suggest that the composition of the parent magma may be a major factor controlling the preference of $\mathrm{Ga}$ in high-Al chromitites.

(2) The positive trend between the $\mathrm{Fe}^{3+} /\left(\mathrm{Al}+\mathrm{Cr}+\mathrm{Fe}^{3+}\right)$ atomic ratio and $\mathrm{Ga}$ content for large chromite deposits may suggest the effect of the redox conditions on the Ga distribution in chromitites.

(3) Plot of the $\mathrm{Cr} /(\mathrm{Cr}+\mathrm{Al})$ atomic ratios versus $\mathrm{Ga}$ content exhibits differences in terms of the slope of correlation lines for the different occurrences, suggesting that, in addition to the composition of parent magmas, other factors such as temperature, pressure or redox conditions may affect the observed deviation from linearity for small metamorphosed chromitite bodies.

(4) The depletion of $\mathrm{Ga}$ and $\mathrm{Al}$, and elevated $\mathrm{Mn}, \mathrm{Co}, \mathrm{Zn}$ and Fe contents in certain small chromitite occurrences, transformed during post-magmatic metamorphism, suggest potential change of the Ga content in Cr-spinel during sub-solidus reactions.

(5) Assuming that low-Cr spinel is characterized by the highest value of the inversion parameter (x) at higher than $650{ }^{\circ} \mathrm{C}$, then the high $\mathrm{Al}$ content in spinels may be a driving force for the degree of inversion in the structure that facilitate the substitution of $\mathrm{Al}^{3+}$ for $\mathrm{Ga}^{3+}$ at magmatic conditions.

Author Contributions: I.-P.D.E. provided the SEM/EDS analyses. Both authors I.-P.D.E. and G.D.E. contributed to the elaboration and interpretation of the data, and carried out the final revision of the manuscript.

Funding: This research was not funded because it is mostly based on valuable literature data.

Acknowledgments: Many thanks are expressed to the National University of Athens for the donations the chromitite samples and the access to the analytical facilities (electron microprobe analysis). Many thanks are expressed to Heinz-Gunter Stosch, Karlsruhe Institute of Technology (KIT), Institute for Applied Geosciences, Germany, Maria Perraki, Technical University of Athens and the anonymous reviewers for the constructive criticism and suggestions on an earlier draft of the manuscript. The linguistic improvement of this work by H.G. Stosch is greatly appreciated.

Conflicts of Interest: The authors declare no conflict of interest.

\section{References}

1. Liu, Z.; Li, H. Metallurgical process for valuable elements recovery from red mud-A review. Hydrometallurgy 2015, 155, 29-43. [CrossRef]

2. Navrotsky, A.; Kleppa, O.J. The thermodynamics of cation distributions in simple spinels. J. Inorg. Nucl. Chem. 1967, 29, 2701-2714. [CrossRef]

3. Shannon, R.D. Revised effective ionic radii and systematic studies of interatomic distances in halides and chalcogenides. Acta Crystallogr. 1976, 32, 751-767. [CrossRef]

4. O'Neill, H.S.C.; Navrotsky, A. Simple spinels: Crystallographic parameters, cation radii, lattice energies, and cation distribution. Am. Mineral. 1983, 68, 181-194.

5. Sickafus, K.E.; Wills, J.M.; Grimes, N.W. Structure of spinel. J. Am. Ceram. Soc. 1999, 82, 3279-3292. [CrossRef]

6. Atkins, P.; Overton, T.; Rourke, J.; Weller, M.; Hagerman, M. Inorganic Chemistry, 5th ed.; W.H. Freeman and Company: New York, NY, USA, 2013.

7. Princivalle, F.; Della Giusta, A.; Carbonin, S. Comparative crystal chemistry of spinels from some suites of ultramafic rocks. Mineral. Petrol. 1989, 40, 117-126. [CrossRef]

8. Bosi, F.; Andreozzi, G.B.; Hålenius, U.; Skogby, H. Zn-O tetrahedral bond length variations in normal spinel oxides. Am. Mineral. 2011, 96, 594-598. [CrossRef]

9. Fregola, R.A.; Bosi, F.; Skogby, S.; Hålenius, U. Cation ordering over short-range and long-range scales in the $\mathrm{MgAl}_{2} \mathrm{O}_{4}-\mathrm{CuAl}_{2} \mathrm{O}_{4}$ series. Am. Mineral. 2012, 97, 1821-1827. [CrossRef]

10. Bosi, F. Chemical and structural variability in cubic spinel Oxides. Acta Crystallogr. 2019, B75, $279-285$. [CrossRef] 
11. Lenaz, D.; Musco, M.E.; Petrelli, M.; Caldeira, R.; De Min, A.; Marzoli, A.; Mata, J.; Perugini, D.; Princivalle, F.; Boumehdi, M.A.; et al. Restitic or not? Insights from trace element content and crystal-Structure of spinels in African mantle xenoliths. Lithos 2017, 278, 464-476. [CrossRef]

12. Wei, C.; Feng, Z.; Scherer, G.G.; Barber, J.; Shao-Horn, Y.; Xu, Z.J. Cations in Octahedral Sites: A Descriptor for Oxygen Electrocatalysis on Transition-Metal Spinels. Adv. Mater. 2017, 29. [CrossRef] [PubMed]

13. Burton, J.D.; Culkin, F.; Riley, J.P. The abundances of gallium and germanium in terrestrial materials. Geochim. Cosmochim. Acta 1959, 16, 151-180. [CrossRef]

14. Paktunc, A.D.; Cabri, L.J. A proton- and electron-microprobe study of gallium, nickel and zinc distribution in chromian spinel. Lithos 1995, 35, 261-282. [CrossRef]

15. Wijbrans, C.H.; Klemme, S.; Berndt, J.; Vollmer, C. Experimental determination of trace element partition coefficients between spinel and silicate melt: The influence of chemical composition and oxygen fugacity. Contrib. Mineral. Petrol. 2015, 169,1-33. [CrossRef]

16. Dare, S.A.S.; Pearce, J.A.; McDonald, I.; Styles, M.T. Tectonic discrimination of peridotites using fO2-Cr\# and Ga-Ti-FeIII systematic in chrome-spinel. Chem. Geol. 2009, 261, 199-216.

17. Gervilla, F.; Padrón-Navarta, J.A.; Kerestedjian, T.; Sergeeva, I.; González-Jiménez, J.M.; Fanlo, I. Formation of ferrian chromite in podiform chromitites from the Golyamo Kamenyane serpentinte, Eastern Rhodopes, SE Bulgaria: A two-stage process. Contrib. Mineral. Petrol. 2012, 164, 643-657. [CrossRef]

18. Colás, V.; González-Jiménez, J.M.; Griffin, W.L.; Fanlo, I.; Gervilla, F.; O’Reilly, S.Y.; Pearson, N.J.; Kerestedjian, T.; Proenza, J.A. Fingerprints of metamorphism in chromite: New insights from minor and trace elements. Chem. Geol. 2014, 389, 137-152. [CrossRef]

19. Scowen, P.; Roeder, P.L.; Helz, R. Re-equilibration of chromite within Kilauea Iki lava lake, Hawaii. Contrib. Mineral. Petrol. 1991, 107, 8-20. [CrossRef]

20. Prasad, S.R.M.; Prasad, B.B.V.S.V.; Rajesh, B.; Rao, K.H.; Ramesh, K.V. Structural and dielectric studies of $\mathrm{Mg}^{2+}$ substituted Ni-Zn ferrite. Mater. Sci. Pol. 2015, 33, 806-815. [CrossRef]

21. Zhou, M.F.; Robinson, P.T.; Su, B.X.; Gao, J.F.; Li, J.W.; Yang, J.S.; Malpas, J. Compositions of chromite, associated minerals, and parental magmas of podiform chromite deposits: The role of slab contamination of asthenospheric melts in suprasubduction zone environments. Gondwana Res. 2014, 26, 262-283. [CrossRef]

22. Uysal, İ.; Tarkian, M.; Sadiklar, M.B.; Zaccarini, F.; Meisel, T.; Garuti, G.; Heidrich, S. Petrology of Al- and Cr-rich ophiolitic chromitites from the Muğla, SW Turkey: Implications from composition of chromite, solid inclusions of platinum-group mineral, silicate, and base-metal mineral, and Os-isotope geochemistry. Contrib. Mineral. Petrol. 2009, 158, 659-674. [CrossRef]

23. Proenza, J.; Gervilla, F.; Melgarejo, J.; Bodinier, J.L. Al- and Cr-rich chromitites from the Mayarí-Baracoa ophiolitic belt (eastern Cuba); consequence of interaction between volatile-rich melts and peridotites in suprasubduction mantle. Econ. Geol. 1999, 94, 547-566. [CrossRef]

24. González-Jiménez, J.M.; Locmelis, M.; Belousova, E.; Griffin, W.L.; Gervilla, F.; Kerestedjian, T.N.; Pearson, N.J.; Sergeeva, I. Genesis and tectonic implications of podiform chromitites in the metamorphosed Ultramafic Massif of Dobromirtsi (Bulgaria). Gondwana Res. 2015, 27, 555-574. [CrossRef]

25. Brough, C.P.; Prichard, H.M.; Neary, C.R.; Fisher, P.C.; McDonald, I. Geochemical variations within podiform chromitite deposits in the Shetland Ophiolite: Implications for petrogenesis and PGE concentration. Econ. Geol. 2015, 110, 187-208. [CrossRef]

26. Konstantopoulou, G.; Economou-Eliopoulos, M. Distribution of Platinum-group Elements and Gold in the Vourinos Chromitite Ores, Greece. Econ. Geol. 1991, 86, 1672-1682. [CrossRef]

27. Economou-Eliopoulos, M.; Parry, S.J.; Christidis, G. Platinum-group element (PGE) content of chromite ores from the Othrys ophiolite complex, Greece. In Mineral Deposits: Research and Exploration. Where Do They Meet? Papunen, H., Ed.; Balkema: Rotterdam, The Netherlands, 1997; pp. 414-441.

28. Economou-Eliopoulos, M.; Vacondios, I. Geochemistry of chromitites and host rocks from the Pindos ophiolite complex, northwestern Greece. Chem. Geol. 1995, 122, 99-108. [CrossRef]

29. Economou-Eliopoulos, M.; Sambanis, G.; Karkanas, P. Trace element distribution in chromitites from the Pindos ophiolite complex, Greece: Implications for the chromite exploration. In Mineral Deposits; Stanley, Ed.; Balkema: Rotterdam, The Netherlands, 1999; pp. 713-716.

30. Economou-Eliopoulos, M. On the origin of the PGE-enrichment in chromitites associated with ophiolite complexes: The case of Skyros island, Greece. In 9th SGA Meeting; Andrew, C.J., Borg, G., Eds.; Digging Deeper: Dublin, Ireland, 2007; pp. 1611-1614. 
31. Economou-Eliopoulos, M. Platinum-group element distribution in chromite ores from ophiolite complexes: Implications for their exploration. Ore Geol. Rev. 1996, 11, 363-381. [CrossRef]

32. Zhelyaskova-Panayiotova, M.; Economou-Eliopoulos, M. Platinum-group element (PGE) and gold concentrations in oxide and sulfide mineralizations from ultmmafic rocks of Bulgaria. Ann. Univ. Sofia Geol. Congr. 1994, 86, 196-218.

33. Rassios, A.; Dilek, Y. Rotational deformation in the Jurassic Meohellenic ophiolites, Greece, and its tectonic significance. Lithos 2009, 108, 192-206. [CrossRef]

34. Economou, M.; Dimou, E.; Economou, G.; Migiros, G.; Vacondios, I.; Grivas, E.; Rassios, A.; Dabitzias, S. Chromite Deposits of Greece: Athens; Theophrastus Publications: Athens, Greece, 1986; pp. 129-159.

35. Kapsiotis, A.; Grammatikopoulos, T.A.; Tsikouras, B.; Hatzipanagiotou, K. Platinum-group mineral characterization in concentrates from high-grade PGE Al-rich chromitites of Korydallos area in the Pindos ophiolite complex (NW Greece). SGS Miner. Serv. 2009, 60, 178-191. [CrossRef]

36. Bonev, N.; Moritz, R.; Borisova, M.; Filipov, P. Therma-Volvi-Gomati complex of the Serbo-Macedonian Massif, northern Greece: A Middle Triassic continental margin ophiolite of Neotethyan origin. J. Geol. Soc. 2018. [CrossRef]

37. Melcher, F.; Grum, W.; Simon, G.; Thalhammer, T.V.; Stumpfl, E. Petrogenesis of the ophiolitic giant chromite deposit of Kempirsai, Kazakhstan: A study of solid and fluid inclusions in chromite. J. Petrol. 1997, 10, 1419-1458. [CrossRef]

38. Barnes, S.-L.; Naldrett, A.J.; Gorton, M.P. The origin of the fractionation of the platinum-group elements in terrestrial magmas. Chem. Geol. 1985, 53, 203-323. [CrossRef]

39. Economou-Eliopoulos, M. Apatite and Mn, Zn, Co-enriched chromite in Ni-laterites of northern Greece and their genetic significance. J. Geochem. Exp. 2003, 80, 41-54. [CrossRef]

40. Sack, R.O.; Ghiorso, M.S. Chromian spinels as petrogenetic indicators: Thermodynamic and petrological applications. Am. Mineral. 1991, 76, 827-847.

41. Pagé, P.; Barnes, S.-J. Using trace elements in chromites to constrain the origin of podiform chromitites in the Thetford Mines Ophiolite, Québec, Canada. Econ. Geol. 2009, 104, 997-1018. [CrossRef]

42. Uysal, I.; Sadiklar, M.; Tarkian, M.; Karsli, O.; Aydin, F. Mineralogy and composition of the chromitites and their platinum-group minerals from Ortaca (Muğla-SW Turkey): Evidence for ophiolitic chromitite genesis. Mineral. Petrol. 2005, 83, 219-242. [CrossRef]

43. Leblanc, M.; Violette, J.F. Distribution of aluminum-rich and chromium-rich chromite pods in ophiolite peridotites. Econ. Geol. 1983, 78, 293-301. [CrossRef]

44. Zhou, M.F.; Sun, M.; Keays, R.R.; Kerrich, R.W. Controls on platinum-group elemental distributions of podiform chromitites: A case study of high-Cr and high-Al chromitites from Chinese orogenic belts. Geochim. Cosmochim. Acta 1998, 62, 677-688. [CrossRef]

45. Zaccarini, F.; Garuti, G.; Proenza, J.A.; Campos, L.; Thalhammer, O.A.R.; Aiglsperger, T.; Lewis, J.F. Chromite and platinum group elements mineralization in the Santa Elena ultramafic nappe (Costa Rica): Geodynamic implications. Geol. Acta 2011, 9, 407-423.

46. Colás, V.; Padrón-Navarta, J.A.; González-Jiménez, J.M.; Griffin, W.L.; Fanlo, I.; O'reilly, S.Y.; Gervilla, F.; Proenza, J.A.; Pearson, N.J.; Escayola, M.P. Compositional effects on the solubility of minor and trace elements in oxide spinel minerals: Insights from crystal-crystal partition coefficients in chromite exsolution. Am. Mineral. 2016, 101, 1360-1372. [CrossRef]

47. Barnes, S.J.; Roeder, P.L. The range of spinel compositions in terrestrial mafic and ultramafic rocks. J. Petrol. 2001, 42, 2279-2302. [CrossRef]

48. Andreozzi, G.B.; Princivalle, F.; Skogby, H.; Della Giusta, A. Cation ordering and structural variations with temperature in $\mathrm{MgAl} 2 \mathrm{O} 4$ spinel: An X-ray single-crystal study. Am. Mineral. 2000, 85, 1164-1171. [CrossRef]

49. Ma, Y.; Liu, X. Kinetics and Thermodynamics of Mg-Al Disorder in $\mathrm{MgAl}_{2} \mathrm{O}_{4}$-spinel: A Review. Molecules 2019, 24, 1704. [CrossRef] [PubMed]

50. Mueller, R.F. Kinetics and thermodynamics of intracrystalline distribution. Mineral. Soc. Am. Spec. Pap. 1969, 2, 83-93.

51. Mueller, R.F. Model for order-disorder kinetics in certain quasi-binary crystals of continuously variable composition. J. Phys. Chem. Solids 1967, 28, 2239-2243. [CrossRef]

52. Martignago, F.; Dal Negro, A.; Carbonin, S. How Cr3+ and Fe3+ affect Mg-Al order disorder transformation at high temperature in natural spinels. Phys. Chem. Miner. 2003, 30, 401-408. [CrossRef] 
53. Princivalle, F.; Martignago, F.; Dal Negro, A. Kinetics of cation ordering in natural $\mathrm{Mg}(\mathrm{Al}, \mathrm{Cr} 3+)_{2} \mathrm{O}_{4}$ spinels. Am. Mineral. 2006, 91, 313-318. [CrossRef]

54. Lavina, B.; Reznitskii, L.Z.; Bosi, F. Crystal chemistry of some Mg, Cr, V normal spinels from Sludyanka (Lake Baikal, Russia): The influence of V3+ on structural stability. Phys. Chem. Miner. 2003, 30, 599-605. [CrossRef] 